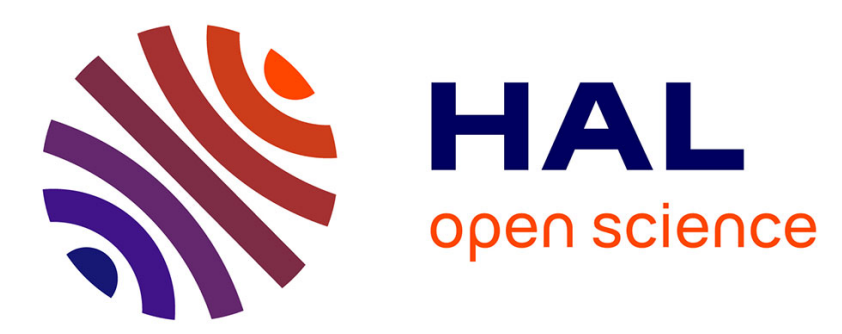

\title{
An estimation of the sand suspension in alpine rivers during a dam flushing event
}

B. Camenen, Fabien Thollet, De Angelis,, Alexis Buffet, Guillaume Dramais, Eric Valette, Sebastien Zanker

\section{- To cite this version:}

B. Camenen, Fabien Thollet, De Angelis,, Alexis Buffet, Guillaume Dramais, et al.. An estimation of the sand suspension in alpine rivers during a dam flushing event. River Flow 2020 (Proceedings of the 10th Conference on Fluvial Hydraulics), Jul 2020, Delft, Netherlands. hal-03118414

\author{
HAL Id: hal-03118414 \\ https://hal.science/hal-03118414
}

Submitted on 4 Feb 2021

HAL is a multi-disciplinary open access archive for the deposit and dissemination of scientific research documents, whether they are published or not. The documents may come from teaching and research institutions in France or abroad, or from public or private research centers.
L'archive ouverte pluridisciplinaire HAL, est destinée au dépôt et à la diffusion de documents scientifiques de niveau recherche, publiés ou non, émanant des établissements d'enseignement et de recherche français ou étrangers, des laboratoires publics ou privés. 


\title{
An estimation of the sand suspension in alpine rivers during a dam flushing event
}

\author{
B. Camenen, F. Thollet, R. de Angelis, A. Buffet, G. Dramais \\ INRAE, UR RiverLy, 5 Rue de la Doua, CS 20244, 69625 Villeurbanne Cedex, France \\ E. Valette \\ EDF-CIH, Savoie Technolac, 73373 Le-Bourget-du-Lac, France
}

S. Zanker

EDF-DTG, 134 Chemin de l'Étang, 38950 Saint-Martin-le-Vinoux, France

\begin{abstract}
A significant amount of sand is transported in piedmont gravel-bed rivers that can often be guessed because of the large quantity of sand found in gravel bars. It is however very difficult to evaluate sand fluxes in such rivers because of the concomitant gravel bedload transport and silt and clay suspension (generally assimilated as washload). Also, actual methods to sample sand suspension and surrogate methods such as acoustics remain difficult to apply because of the large velocities and high washload concentrations observed during floods. In this paper, we estimated sand suspension in two gravel-bed alpine rivers during a flushing event (in May 2018 in the Isère River and in June 2019 in the Arc River). Two systems to measure sand flux were evaluated and compared through some simple modelling: a Delft bottle and a peristaltic pump associated to measurements of the flow velocity (ADCP or radar). The objective is to test and validate the pumping system, which is easier to deploy and to collect multiple samples but not as accurate as isokinetic samplers. If the Delft bottle may underestimate the sand flux for high flow velocities, there is a large risk of overestimation using a peristaltic pump since the intake velocity is often much smaller than the flow velocity. Eventually, such experiments allowed us to propose a first evaluation of the sand flux in alpine rivers during a flushing event. It was found that sand fluxes during these events were of the same order of magnitude than Suspended Particulate Matter (SPM) fluxes evaluated from the hydro-sedimentary stations.
\end{abstract}

\section{INTRODUCTION}

A significant amount of sand is transported in piedmont gravel-bed rivers. To the authors knowledge, there is however very few measurements made because of the experimental difficulties. Indeed, sand suspension is difficult to evaluate because of the spatial and temporal variation of sand concentration throughout the river cross-section. Moreover, in alpine rivers, high velocities and the concomitant gravel bedload transport and silt and clay suspension (generally assimilated as washload) significantly limit the possibility to sample. It is also more complex to apply surrogate techniques such as acoustics, which need anyway to be calibrated with samples (Gray and Gartner, 2009, Topping and Wright, 2016). As a consequence, the presence of sand fluxes is often only guessed because of the large quantity of sand found in gravel bars (Bridge, 1993, Camenen et al., 2016).

Following the first attempt by Camenen et al., 2018b, in a secondary channel, we proposed here to measure sand suspension in gravel-bed alpine rivers using a peristaltic pump. Such system would be easier to deploy and to collect multiple samples. However, it is not as accurate as isokinetic samplers (Gray and Landers, 2014). To be able to validate the pumping system, it is compared to a Delft bottle, which allows a time-averaged and isokinetic sample. Two test cases are presented: the first one using an ISCO sampler on the Isère River during a dam flushing event in May 2018, the second one using an Albin Pump ALP17 on the Arc River during a dam flushing 
event in June 2019. A discussion is provided on the validity of the peristaltic pumps especially in case of non-isokinetic sampling for high pressure heads when measuring from a bridge. Also, based on the same measurements, a first evaluation of the sand flux in the two alpine rivers is provided for specific dam flushing events.

\section{FIELD MEASUREMENTS}

\subsection{Location of the field measurements}

The Arc-en-Maurienne and Isère rivers are constricted alpine rivers characterized by a nival hydrologic regime and marked by an intense input of fine sediments from the catchment. The two experimental sites are on bridges located, respectively (see Figure 1):

- in the Arc River at Ste-Marie-de-Cuines, $10 \mathrm{~km}$ downstream of St-Jean-de-Maurienne with a mean slope of $0.6 \%$. The experiment was conducted during a flushing event of the three run-of-the-river dams on 18th June 2019;

- in the Isère River at Pont-de-Grésy, $10 \mathrm{~km}$ downstream of Albertville with a mean slope of $0.2 \%$. The experiment was conducted during the flushing event of the Aigueblanche dam.

One point of interest of these sites is that dam flushing events are conducted regularly allowing the performance of in-situ experiments at a specified date known in advance. For the Arc River dam flush, the date is defined a few months in advance; for the Aigueblanche dam flush on the Isère River, the trigger of the dam flushing event is determined by hydrological conditions, and so the date is known one week in advance only. Topographic, bathymetric and flow measurements are regularly carried out during and around these flushing events. Bedload transport was assessed on the same site on the Arc River using a bedload sampler from a bridge (Camenen et al., 2012).

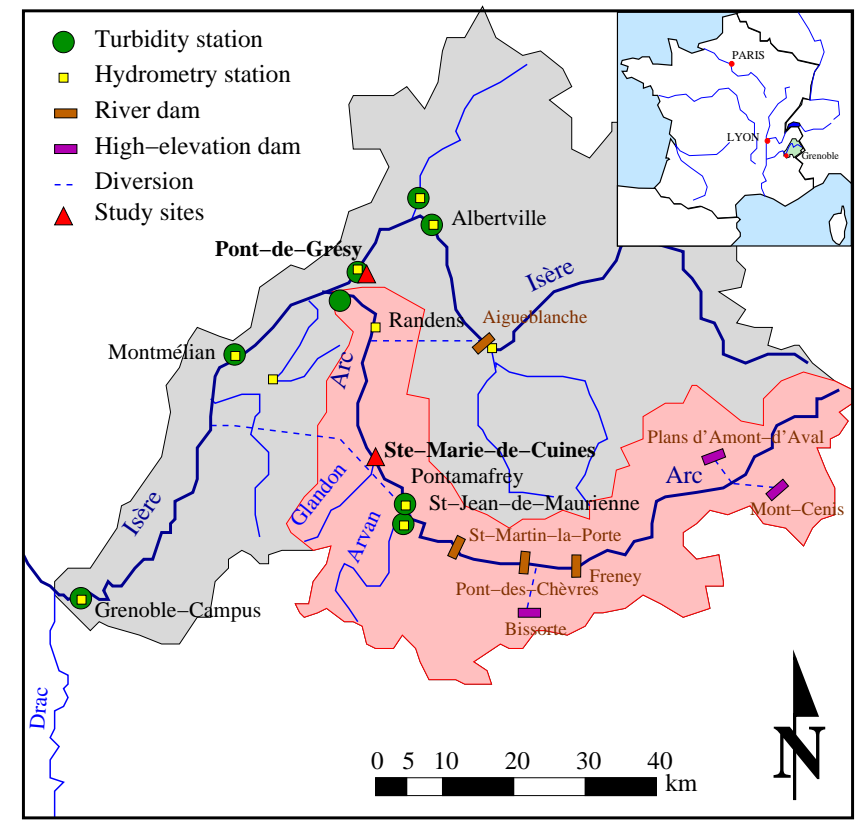

Figure 1. Location map of the two experimental sites: Ste-Marie-de-Cuines and Pont-de-Grésy (Isère catchment upstream of Grenoble).

\subsection{Hydro-sedimentary measurements}

For each of the experimental sites, the discharge time series is recorded at hydrometric stations located $8 \mathrm{~km}$ upstream at Pontamafrey, and on site at Pont-de-Gresy, respectively (see Fig. 2). Fine suspension concentration time series are also available thanks to a calibrated turbidity-meter deployed at each station. Additional local flow measurements were made either using an ADCP (Sontek M9) or Surface Velocity Radar (Decatur SVR). Local water depths were calculated 
using a pressure sensor fixed on the frame of the Delft bottle (approximately $10 \mathrm{~cm}$ above the bed). For each of the sites, a bathymetry profile of the cross-section was measured using ADCP measurements or bathymetric measurements using a theodolite (Leica TC205).

It should be noted the event on the Isère River in May 2018 actually included three days of flushing only (from 06/05/2018 05:00 to 09/05/2018 08:30). During this period, the bottom gates of the Aigueblanche dam were opened. Then, the reservoir was filled until 11/05/2018 and the flood passed by the surface gates.

(a)

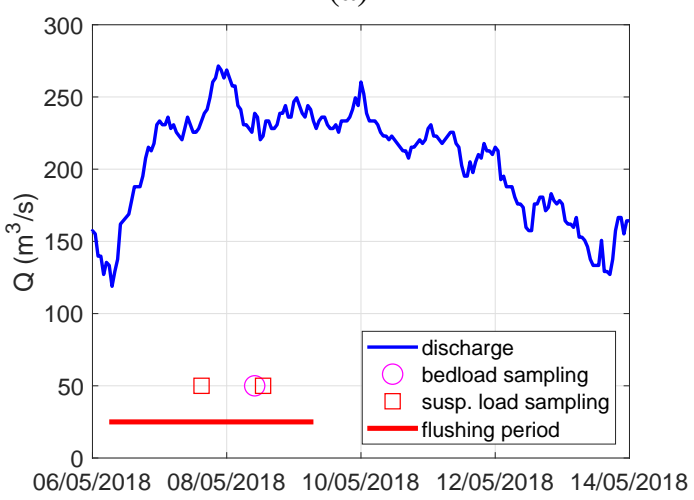

(b)

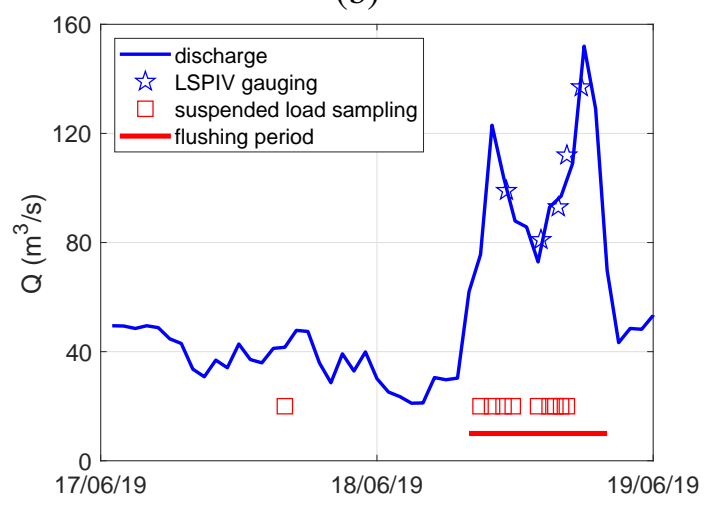

Figure 2. Discharge time series and main experimental sampling: (a) Isère River at Pont-de-Grésy in May 2018, (b) Arc River at Ste-Marie-de-Cuines in June 2019 (sediment samplings are indicated for an arbitrary water discharge).

\subsection{Sand flux measurements}

Some bedload measurements were made during the Isère campaign using a ToutleRiver 2 sampler with a $0.2 \mathrm{~mm}$ mesh together with acoustic (hydrophone) measurements (Zanker, 2019). Comparisons made with the same sampler with a $1 \mathrm{~mm}$ mesh showed some large differences both in the mass collected and the Grain Size Distribution. Based on the results by Geay et al., 2018, Zanker, 2019, evaluated that bedload measurements could be underestimated by an order of magnitude.

For both campaigns, a Delft bottle was deployed from the bridge using a jib-crane. samples were collected for a 5 to 10 min duration at different position above the bed $(10$ to $60 \mathrm{~cm})$. The Delft bottle will be used as a reference although some limits have been discussed, such as the underestimated collection of the finest sand particles (Beverage and Williams, 1989). At velocities above $2.5 \mathrm{~m} / \mathrm{s}$, Dijkman and Milisic, 1982, pointed out that errors may increase significantly since a larger part of the sediments are flushed through the device. However, the Delft Bottle provides a better time-averaging than systems collecting the entire mass of water and sediments such as the P61 (Beverage and Williams, 1989).

Samples using a peristaltic pump were collected simultaneously by fixing the pipe on the side of the Delft bottle, facing the flow. During the Isère campaign, an ISCO sampler was used whereas an Albin Pump ALP17 was used on the Arc River, the later being more powerful than the former. Indeed, one important issue for the peristaltic pump is the sampling intake velocity that is strongly limited by the height above the river surface. The ISCO sampler could hardly reach an intake velocity of $U_{n} \approx 0.4 \mathrm{~m} / \mathrm{s}$ whereas the depth-averaged flow velocity was $U \approx 2.5 \mathrm{~m} / \mathrm{s}$. For the campaign on the Arc River with the Albin pump, the maximum pumping velocity was used $\left(U_{n} \approx 0.8 \mathrm{~m} / \mathrm{s}\right.$ ) for a depth-averaged flow velocity varying between 2 and $3 \mathrm{~m} / \mathrm{s}$. Based on Gray and Landers, 2014, one could expect a significant over-estimation of the sand concentrations using the pumping systems for both campaigns. Samples taken from both pumps were of 0.51 approximately; the whole volume was analysed in the laboratory following Dramais et al., 2018's recommendation, i.e. with a sand separation before analysis according to US standards. However, with the Albin Pump, one could sample large volumes to reduce the uncertainties. 


\section{MODEL AND RESULTS}

In order to better understand and validate our measurements, they were compared to a sediment transport model (Camenen and Larson, 2008) and they were used to build a sediment rating curve as proposed by Camenen et al., 2014.

\subsection{Model}

The sand concentrations were estimated using the Camenen and Larson, 2008, equations. For a steady current, they yield an exponential profile for concentration since the sediment diffusivity $\epsilon_{s}$ is assumed constant over the water depth :

$$
C(z)=C_{R} \exp \left(-\frac{W_{s}}{\epsilon_{s}} z\right)
$$

where $W_{s}$ is the settling velocity of the sand particles of diameter $d_{s}$, and $C_{R}$ is a reference concentration expressed as follows :

$$
C_{R}=\mu 1.5 \times 10^{-3} \rho_{s} \exp \left(-0.2 D_{s}\right) \theta \exp \left(-4.5 \frac{\theta_{c r}}{\theta}\right)
$$

with $\mu$ is the sand content in the bed layer, $D_{s}=\left[g\left(\rho_{s} / \rho-1\right) / \nu^{2}\right]^{1 / 3} d_{s}$ the dimensionless grain size ( $g$ : acceleration of gravity; $\rho_{s}$ : sediment density; $\nu$ : kinematic viscosity), $\theta=\tau /\left[\left(\rho_{s}-\rho\right) g d_{s}\right]$ the Shields number ( $\tau$ : bed shear stress; $\rho$ : water density) and $\theta_{c r}$ its critical value for inception of movement. The sediment diffusivity is calculated as follows :

$$
\epsilon_{s}=\frac{1}{6} \kappa u_{*} h
$$

where $\kappa=0.41$ is the Von Karman constant, $u_{*}=(\tau / \rho)^{1 / 2}$ the friction velocity and $h$ the mean water depth.

\subsection{Vertical sand concentration}

In Fig. 3, we plotted vertical sand flux profiles $\phi(z)=u(z) C(z)$ obtained both from the model (using different values for the bed sand content $\mu$ and specific hydraulic conditions) and from experimental data (Delft bottle and pumping systems). The time-averaged streamwise velocity $u(z)$ was evaluated assuming a logarithmic velocity profile with a roughness length $k_{s}=2 d_{90}=$ 0.15 and $0.05 \mathrm{~m}$, for the Arc and Isère sites, respectively $\left(d_{90}\right.$ : grain diameter for which $90 \%$ of the distribution has a smaller particle size, based on measurements made on the side of the main channel using the Wolman pebble count procedure). $C(z)$ was evaluated using Eqs. 1, 2, and 3 using a sand diameter $d_{s}=0.27$ and $0.20 \mathrm{~mm}$, for the Arc and Isère sites, respectively. These values correspond to the average median grain size diameter of all Grain Size Distribution (GSD) of the Delft bottle samples. One should note that pump samples generally yielded a finer GSD.

For the Isère campaign, one can observe concentrations twice larger using the ISCO sampler compared to the Delft bottle (Fig. 3a). The Delft bottle was used outside its range of validity $(U \approx 2.5 \mathrm{~m} / \mathrm{s}$ ); we extrapolated the efficiency coefficient $k$ and thus assumed $k \approx 1)$. This could lead to some underestimation of the sand flux by the Delft bottle and a bias (underestimation of the fin fraction of the GSD) (Dijkman, 1978, Beverage and Williams, 1989). Despite this limit of our reference, our results confirm a potential impact of the non-isokinetic sampling as discussed by Gray and Landers, 2014. Tehy estimated an overestimation approximately equal to $50 \%$ for an intake velocity 5 times smaller as the flow velocity and a grain size $d_{s} \approx 0.2 \mathrm{~mm}$. Another issue from the ISCO sampler is that the sample is filled directly while some delay exists for coarsest particles due to their settling velocity. The model is able to yield satisfactory results assuming a bed composed of $15 \%$ of sand (i.e; for $\mu=0.15$, or with $\mu=0.30$ considering ISCO data). It behaves correctly showing a lower flux close to the bed $(z / h<0.1)$.

For the Arc campaign, it was not as easy to plot all results in a single figure since hydrodynamics conditions were varying a lot during the measurements (Fig. 3b). However, one can observe that the quantity of sand available in the system significantly increased during the flushing event. Indeed, measurements made the day before the flushing event were correctly reproduced by the model using $\mu=0.1$ (data points for which $\Phi<2 \mathrm{~kg} / \mathrm{m}^{2} / \mathrm{s}$ ) whereas measurements made during 
(a)

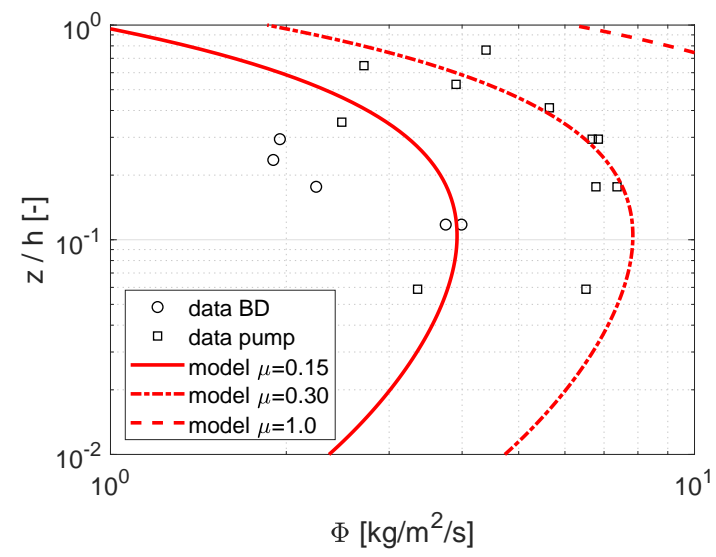

(b)

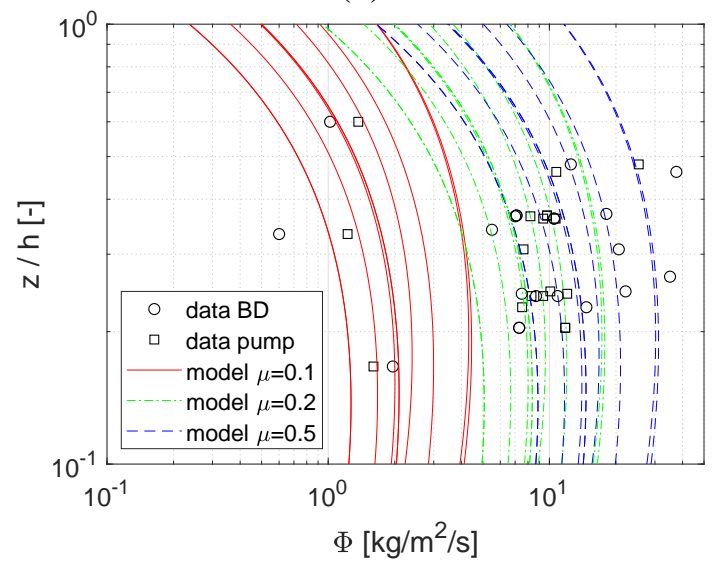

Figure 3. Comparison between modelled and measured vertical sand flux profile assuming different sand contents of the bed $(\mu)$ : (a) Isère River at Pont-de-Grésy, (b) Arc River at Ste-Marie-de-Cuines.

the flushing event were roughly reproduced using $\mu=0.5$ (data points for which $\Phi>5 \mathrm{~kg} / \mathrm{m}^{2} / \mathrm{s}$ ). Surprisingly, no clear differences were observed between Delft bottle results and Albin Pump results although the later intake velocity was 2 to 3 times smaller than the flow velocity. Based on Gray and Landers, 2014, it would yield an overestimation of the concentration by $20 \%$ approximately. But sampling uncertainties may hinder this possible bias. Also, one should have in mind that time-averaging for pump samples was much smaller for our specific case. Samples from the Delft bottle were generally coarser. This could be related to the bias linked to a sediment loss of the finest sand particles. We found however coarse particles $(d>1 \mathrm{~mm})$, which were not sampled by the pumping system. The settling velocity $W_{s}$ of these particles remains much smaller than the intake velocity $\left(W_{s} \approx 0.2 \mathrm{~m} / \mathrm{s}\right.$ for $d=2 \mathrm{~mm}$ ); we were also careful to wait for some steady regime before sampling to avoid possible bias linked to direct sampling such as for the ISCO sampler as discussed before. So, we suspect this bias in the grain size distribution to be linked to too low intake velocity in respect to the flow velocity.

\subsection{Sand fluxes during the flushing events}

As proposed by Camenen et al., 2014, it is possible to build a sediment rating curve based on the stage-discharge relationship, the cross-section bathymetry of the station, and sediment characteristics. Such model could be adjusted using a coefficient for the sediment transport formula, which was made here using a "calibrated" sand content in the bed $\mu$ as discussed above. Sand transport rating curves for both Isère River at Pont-de-Grésy and Arc River at Ste-Marie-de-Cuines are presented in Fig. 4 using $\mu=0.15$ and 0.5 , respectively.

For the Isère River case, since the river section is not homogeneous with a deeper channel close to the right bank, sand flux calculations were made using either section-averaged parameters ( $Q_{s b m}$ and $Q_{s s m}$ for the bedload and suspended load fluxes, respectively) or after distributing bed shear stress throughout the cross-section $\left(\Sigma Q_{s b i}\right.$ and $\Sigma Q_{s s i}$ for the bedload and suspended load fluxes, respectively) to take into account water depth variability (Camenen et al., 2011). For the specific case of the Isère River, one can observe huge differences with an order of magnitude. The only suspended load measurement available shows that the second rating curve (with distributed bed shear stresses) is in a better agreement with data. For bedload, measurements indicate a relatively low bedload transport. However, this value is highly uncertain for this case. Indeed, results were quantitatively and qualitatively very sensitive to the mesh size of the net: gravel material was mostly sampled using a $1 \mathrm{~mm}$ mesh, and sand was prevailing using a $0.1 \mathrm{~mm}$ mesh (Zanker, 2019). As discussed before, Zanker, 2019, evaluated an underestimation by a factor 10 based on hydrophone measurements.

For the Arc River case, we used the cross-section-averaged parameters since the cross-section is more homogeneous. The sediment rating curve (with $\mu=0.5$ ) yields relatively good results for the flushing period. The data point at $Q=45 \mathrm{~m}^{3} / \mathrm{s}$ is indeed overestimated but it corresponds to measurements done the day before the flushing event with a much lower sand content $(\mu \approx 0.1$ in 
Fig. 3b). The bedload rating curve appears to be unrealistic; it should be noted however that we did not take into account hiding effects.

(a)

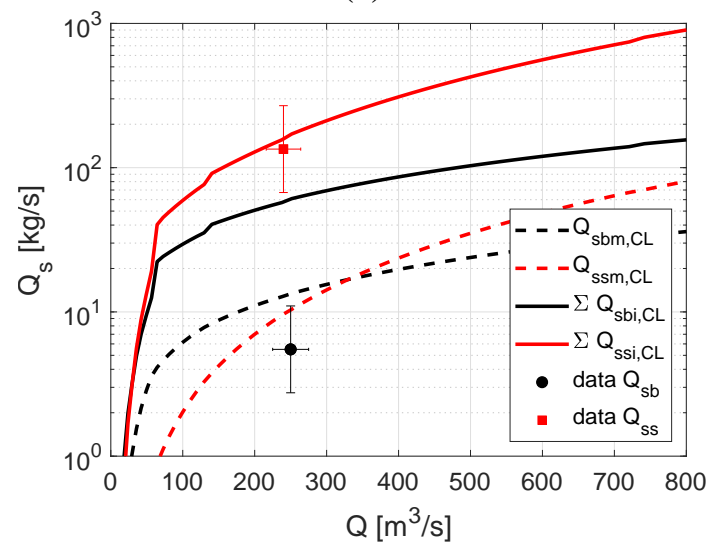

(b)

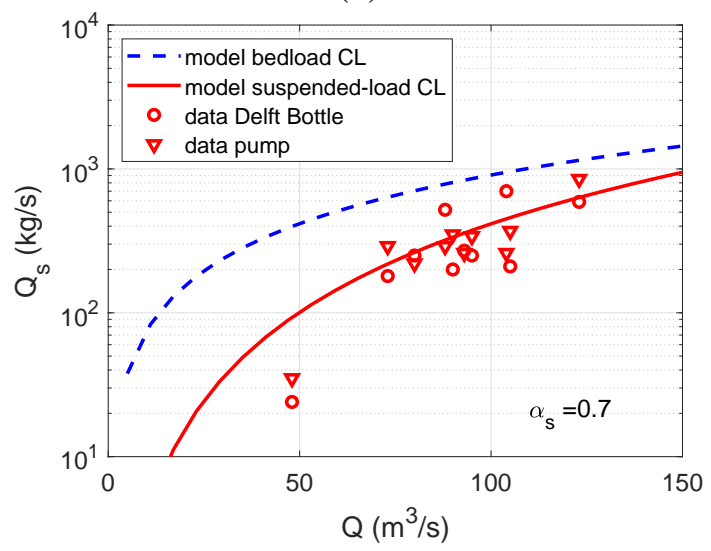

Figure 4. Estimation of the sand rating curves during flushing events: (a) Isère River at Pont-de-Grésy, (b) Arc River at Ste-Marie-de-Cuines.

Thanks to the sediment rating curves, assuming they are valid for the total flushing period, it is possible to evaluate the total sand load over the event (see Tab. 1). One can observe a total suspended-load of sand of 16000 and 40000 tons for the Arc and Isère flushing events, respectively.

Such values can be compared to Suspended Particulate Matter (SPM) fluxes estimated at the hydro-sedimentary stations. These measurements are based on a calibrated turbidity-meter positioned on the side of the river. Because of the relatively low velocities and the sensitivity of turbidity to grain size (inversely proportional to $d$, see Foster et al., 1992), we assessed it measures fine SPM only, i.e. excluding sand. Indeed, one important hypothesis for such hydro-sedimentary station is that concentration is homogeneous throughout the river section, which is not the case for sands. In the case of the Grésy station, we assumed a linear relationship between turbidity and concentration $\left(C_{S P M}=\alpha T\right.$ where $T$ is the turbidity expressed in $\mathrm{g} / \mathrm{l}$ and $\alpha=1.2$ a calibration coefficient), mostly validated on low concentrations. Indeed, we suspected water samples taken during the event to often include sands that could bias the calibration (Camenen et al., 2018a). We obtained a total fine SPM flux of approximately 30,000 and 130,000 tons for the Arc and Isère flushing events, respectively (180,000 tons for the whole Isère flood event). As discussed previously, the May 2018 event on the Isère River actually included three days of flushing only. For both cases, these values are consistent with what is usually observed during dam flushing events (Antoine et al., 2013, Némery et al., 2013).

Our estimation for the total sand suspension flux during the events eventually indicates values of the same order of magnitude (a factor 3 smaller). Thus, sand suspension would be far from being negligible in the total load. Such result is confirmed by the large amount of sand observed over gravel bars. Indeed, sand content in surface deposits varies from 50\% to $70 \%$.

Table 1. Estimation of the total sand suspension $M_{\text {sand }}$ and SPM $M_{S P M}$ fluxes during the flushing events $\left(Q_{\max }\right.$ : maximum water discharge, $\Delta t$ : duration of the event).

\begin{tabular}{l|ccccc}
\hline station & date & $\begin{array}{c}Q_{\max } \\
\left(\mathrm{m}^{3} / \mathrm{s}\right)\end{array}$ & $\begin{array}{c}\Delta t \\
\text { (days) }\end{array}$ & $\begin{array}{c}M_{S P M} \\
\text { (tons) }\end{array}$ & $\begin{array}{c}M_{\text {sand }} \\
\text { (tons) }\end{array}$ \\
\hline Isère River at Pont-de-Grésy & May 2018 & 270 & 7.0 & $1.3 \times 10^{5}$ & $4.0 \times 10^{4}$ \\
Arc River at Ste-Marie-de-Cuines & June 2019 & 150 & 0.5 & $2.7 \times 10^{4}$ & $1.6 \times 10^{4}$
\end{tabular}




\section{CONCLUSION}

Sand suspension measurements were achieved using peristaltic pumps and a Delft bottle, the later being used as a reference. A bias (overestimation) was clearly observed linked to the nonisokinetic sampling if the intake velocity was much smaller than the flow velocity. This is the main limit of peristaltic pumps that are often not powerful enough to reach high intake velocities. Submerged pumps are much more efficient to maintain an iso-kinetic velocity in such environment but are more fragile towards coarse particles (Recking et al., 2020). Also, if this difference is less than a factor 2 , this bias may be masked by other sampling uncertainties. Indeed, Gray and Landers, 2014, found for sediments finer than $0.5 \mathrm{~mm}$ a maximum overestimation of $30 \%$ for a velocity ratio $U / U_{n} \leq 2$. This could validate the use of peristaltic pumps for sand sampling if the pressure head is not too large. Indeed, such pumps allow a much more efficient sampling since they do not require a long manipulation to sample (no need to get the sampler out of water to collect the sample). Additional validation is however needed to confirm these first results.

Sand suspension measurements in alpine rivers (Arc, Isère, France) were eventually presented suggesting that large concentrations of sand can be observed in such rivers during flushing events. Eventually, we found that sand fluxes during flushing events are of the same order of magnitude of SPM fluxes. As a consequence, it points out the limits of the turbidity-meter station network set in many rivers to establish a fine sediment budget. At least, the turbidity-meter should be calibrated specifically for each significant events. Indeed, a turbidity-meter station cannot include sand suspension properly because of the low sensitivity of turbidity to coarse particles. A major issue is thus to be able to measure continuously sand concentrations, acoustics being one of the possible surrogate techniques (Topping and Wright, 2016).

\section{Acknowledgements}

This study was supported by INRAE, EDF-CIH, and by the French National Research Agency (ANR) under the grant ANR-18-CE01-0020 (DEAR project). The 2018 campaign on the Isère River was also supported by EDF-DTG and EDF-LNHE for the flow measurements and sand sampling.

\section{REFERENCES}

Antoine, G., Jodeau, M., Camenen, B., Esteves, M., Némery, J., and Lauters, F. (2013). Estimation des flux de matières en suspension lors des chasses hydrauliques de l'Arc de 2006 à 2011. La Houille Blanche, 4:43-49. (in French).

Beverage, J. P. and Williams, D. T. (1989). Comparison - us p-61 and delft sediment samplers. Journal of Hydraulic Engineering, 115(2):1702-1706.

Bridge, J. S. (1993). Description and interpretation of fluvial deposits: a critical perspective. Sedimentology, 40(2):801-810.

Camenen, B., Buffet, A., Thollet, F., Lacroix, F., Liger, L., and Pénard, L. (2018a). Expérience de terrain lors de la chasse de la retenue d'Aigueblanche sur l'Isère (6 au 10 mai 2018) pour l'estimation de la dynamique des particules sableuses [Field experiment on the Isère River during the Aigueblanche flushing event to evaluate sand dynamics]. Technical report, Irstea/EDF-CIH. (in French).

Camenen, B., Dramais, G., Buffet, A., Thollet, F., Le Bescond, C., Lagouy, M., Berni, C., and Le Coz, J. (2018b). Estimation of sand suspension in a secondary channel of an alpine river. In Paquier, A., Rivière, N., and Khaladi, A., editors, River Flow, Proc. 9th Int. Conf. on Fluvial Hydraulics, number 04014 in E3S Web of Conferences 40, pages 1-8, Lyon, France.

Camenen, B., Herrero, A., Perret, E., Berni, C., Thollet, F., Buffet, A., Dramais, G., Le Bescond, C., and Lagouy, M. (2016). Estimation of the volume of a fine sediment deposit over a gravel bar during a flushing event. In River Flow, Proc. 8th Int. Conf. on Fluvial Hydraulics, page 8p., St Louis, Missouri, USA.

Camenen, B., Holubová, K., Lukač, M., Le Coz, J., and Paquier, A. (2011). Assessment of methods used in 1D models for computing bed-load transport in a large river: the Danube River in Slovakia. Journal of Hydraulic Engineering, 137(10):1190-1199.

Camenen, B., Jaballah, M., Geay, T., Belleudy, P., Laronne, J. B., and Laskowski, J. P. (2012). Tentative measurements of bedload transport in an energetic alpine gravel bed river. In Murillo Mũnoz, R. E., editor, River Flow, Proc. 6th Int. Conf. on Fluvial Hydraulics, pages 379-386, San Jose, Costa Rica.

Camenen, B. and Larson, M. (2008). A general formula for noncohesive suspended sediment transport. Journal of Coastal Research, 24(3):615-627. 
Camenen, B., Le Coz, J., Dramais, G., Peteuil, C., Fretaud, T., Falgon, A., Dussouillez, P., and Moore, S. A. (2014). A simple physically-based model for predicting sand transport dynamics in the Lower Mekong River. In Schleiss, A. J., de Cesare, G., Franca, M. J., and Pfister, M., editors, River Flow, Proc. 7th Int. Conf. on Fluvial Hydraulics, pages 2189-2197, Lausanne, Switzerland.

Dijkman, J. (1978). Some characteristics of USP-61 and Delft Bottle suspended sediment samplers. Technical report, Delft Univ. of Technology, The Netherlands. 211 p.

Dijkman, J. and Milisic, V. (1982). Investigations on suspended sediment samplers based on measurements in the Danube River, May 1979. Technical Report S410, Delft Hydraulics Laboratory and Jaroslav Cerni Institute, The Netherlands.

Dramais, G., Camenen, B., and Le Coz, J. (2018). Comparaison de méthodes pour la mesure des matières en suspension dans les cours d'eau en présence de sable [Methods comparison for river suspended sediment measurements containing sand]. La Houille Blanche, 5-6:96-105. (accepted).

Foster, I. D. L., Millington, R., and Grew, R. G. (1992). The impact of particle size controls on stream turbidity measurements; some implications for suspended sediment yield estimation. In Bogen, J., Walling, D. E., and Day, T. J., editors, Erosion and Sediment Transport Monitoring Programmes in River Basins, pages 51-62. IAHS Publication No. 210.

Geay, T., Zanker, S., Hauet, A., Misset, and Recking, A. (2018). An estimate of bedload discharge in rivers with passive acoustic measurements: Towards a generalized calibration curve? In Paquier, A., Rivière, N., and Khaladi, A., editors, River Flow, Proc. 9th Int. Conf. on Fluvial Hydraulics, volume E3S Web of Conferences 40 of 044009 , pages 1-8, Lyon, France.

Gray, J. and Landers, M. (2014). Measuring suspended sediment. In Ahuja, S., editor, Comprehensive Water Quality and Purification, chapter 4, pages 159-204. Elsevier.

Gray, J. R. and Gartner, J. W. (2009). Technological advances in suspended-sediment surrogate monitoring. Water Resources Research, 45(W00D29):1-20.

Némery, J., Mano, V., Coynel, A., Etcheber, H., Moatar, F., Meybeck, M., Belleudy, P., and Poirel, A. (2013). Carbon and suspended sediment transport in an impounded alpine river (Isère, France). Hydrological Processes, 27:2498-2508.

Recking, A., Lauters, F., Zanker, S., Regazzoni, M., Geay, T., Camenen, B., Brunet, L., and Fontaine, F. (2020). Measurement of sand transport with a submerged pump: presentation of the results of a test campaign carried out on the Is're River in July 2019. In River Flow, Proc. 9th Int. Conf. on Fluvial Hydraulics.

Topping, D. J. and Wright, S. A. (2016). Long-term continuous acoustical suspended-sediment measurements in rivers - theory, application, bias, and error. Professional Paper 1823, U. S. Geological Survey.

Zanker, S. (2019). Combe de Savoie - Estimation du charriage pendant la chasse d'Aigueblanche 2018 [Combe de Savoie - Bedload flux estimation during the Aigueblanche dam flushing event of May 2018]. techreport 05-2019-000010, EDF-DTG. (in French). 